\title{
EARLY IOWA MAP ATTRACTS SETTLERS
}

By B. L. WICK*

An Iowan recently traveling in the east brought back from Morris, N. Y. an old township map of Iowa published and circulated in 1854 by Henn, Williams \& Company, of Fairfield. A number of ferries and prospective railway routes, as well as some roads already were laid out as shown by this map.

With settlements largely in the eastern sections of the state, the map discloses that Linn county then had post offices as follows: Cedar Rapids, Marion, Newark, Hoosier Grove, Palo, Ivanhoe, St. Mary's, St. Julien, Oak Grove, Spencer Grove, Lafayette, Boulder, Center Point and Cedar.

Johnson county shows up with post offices at Iowa City, Solon, Old Man's Creek, Ft. Pierce and New Port, while Benton county had for post offices then Vinton, Burke, Marysville, Benton, Taylor's Grove and Prairie Creek.

Iowa county had post offices at Marengo, Kozta, Homestead, Millersburg and North English.

Jones county shows post offices at Anamosa, Scotch Grove, Monticello, Fairview, Springfield, Highland, Castle Grove, Bowen's Prairie, Rome and Walnut Fork.

Cedar county being settled prior to the other counties, the following were shown: Tipton, Rochester, Inland, Cedar Bluffs, Masillon, Pioneer, Yankee Grove, Springdale and Pedee.

Twenty counties and more in the northwestern section of Iowa showed neither post offices nor roads upon this map.

Published by Iowa men this map was circulated all over the eastern states and undoubtedly was the means of securing a great many of the early settlers who emigrated to Iowa in the fifties and located in the eastern portion of the new state then scarcely five years old with large tracts of land thrown open for settlement.

\footnotetext{
B. L. Wick is president of the Linn County Historical Society and an authority on eastern Iowa historical matters.
} 
Bernhart Henn lived at Fairfield, was a lawyer and served in the Thirty-second and Thirty-third congresses as one of the Iowa representatives from 1851 to 1855 . He was a widely known citizen who originally came to Iowa from New York and first settled at Burlington, later becoming clerk in the United States land office and in 1844 registrar of the land office at Fairfield. As a public official and a business man he was credited with being aggressive, forceful, with a dominating personality and inclined to be dictatory in his political views.

Mr. Henn organized the banking firm known as Henn, Williams \& Company at Fairfield. Mr. Williams came to Iowa earlier and with George D. and Ed. Temple, organized the first bank in Fairfield, where he resided in 1851. Henn also published a paper in Iowa City for a short time. He died in 1865. His widow survived him until 1895, having been born in Maryland in 1820 .

\section{WATERFOWL IN IOWA}

The extensive collection of mounted specimens of Iowa waterfowl, bird skins, motion pictures and slides at the State Department of History and Archives have been of major importance in the development of the text and splendid color plates of a new 130 page book that has recently been completed by Jack W. Musgrove and Mary R. Musgrove. The volume is now in press; the superb colored plate illustrations are by Maynard F. Reece.

Included in the text are all species of waterfowl which have occurred in the state. Brief life histories place major emphasis on the bird's habitat, behavior, field marks and status in Iowa. The color plates, truly exceptional work of art, show the birds in their various plumage phases. This volume will at once find favor with lovers of wildlife and is being published by the State Conservation Commission. 
Copyright of Annals of Iowa is the property of State of Iowa, by \& through the State Historical Society of Iowa and its content may not be copied or emailed to multiple sites or posted to a listserv without the copyright holder's express written permission. However, users may print, download, or email articles for individual use. 